\title{
DIABETES INSIPIDUS COMPLICATING TOTAL ADRENALECTOMY
}

\author{
BY \\ J. R. REES* AND JOAN F. ZILVA \\ From Westminster Hospital, London
}

(RECEIVED FOR PUBLICATION MAY 10, 1959)

Diabetes insipidus is seldom complicated by other hormonal defects. As far as we know only one patient with diabetes insipidus and adrenal insufficiency has previously been described (Skillern, Corcoran, and Scherbel, 1956), although a number of patients with loss of both anterior and posterior pituitary function have been reported (Leaf, Mamby, Rasmussen, and Marasco, 1952 ; Engstrom and Liebman 1953; Lipsett and Pearson, 1957). Because of the difficulties encountered in the management of combined diabetes insipidus and adrenal insufficiency, the following case is recorded.

\section{Case Report}

In 1947 a married woman, aged 54, developed carcinoma of the left breast, which was treated by radical mastectomy and local irradiation. She remained well until March, 1957, when malaise, loss of weight, and widespread bone pain developed. There was no local recurrence, but radiographs revealed extensive pulmonary and osseous metastases, particularly involving the femora, pelvis, and skull with erosion of the sella turcica. After oophorectomy and total adrenalectomy, performed by Sir Stanford Cade, the patient's post-operative course was uneventful and she was discharged in May, 1957, taking $50 \mathrm{mg}$. cortisone daily by mouth. She felt well enough to convalesce abroad, but a month later noticed a recurrence of malaise with increasing thirst and polyuria. Despite increasing the dose of cortisone to $125 \mathrm{mg}$. daily and taking extra salt, she deteriorated rapidly, became comatose and was admitted to hospital again on June 23, 1957 (Day 1, Fig. 1).

On entry she was mentally confused and extremely dehydrated. The pulse was $120 / \mathrm{min}$. and of small volume with a blood pressure of $100 / 70 \mathrm{~mm}$. $\mathrm{Hg}$ compared with $135 / 80 \mathrm{~mm}$. $\mathrm{Hg}$ the previous month. The haemoglobin level was $19.2 \mathrm{~g} . \%$ in contrast to a previous value of $10.8 \mathrm{~g} . \%$, and the serum electrolytes were as shown in the following table.

*Present address: Guy's Hospital, London.

\begin{tabular}{|c|c|c|}
\hline & $\begin{array}{l}\text { On Entry in } \\
\text { June, } 1957\end{array}$ & $\begin{array}{l}\text { May, } \\
1957\end{array}$ \\
\hline $\begin{array}{l}\text { Sodium } \\
\text { Potassium } \\
\text { Chloride } \\
\text { Total protein }\end{array}$ & $\begin{array}{c}177 \mathrm{mEq} / \mathrm{l} . \\
3.3 \quad " \\
140.9 \mathrm{~g} . \%\end{array}$ & $\begin{array}{c}146 \mathrm{mEq} / \mathrm{l} . \\
4.9 \quad, \\
108 \\
7.0 \mathrm{~g} . \%\end{array}$ \\
\hline
\end{tabular}

The history of thirst and polyuria together with the dehydration and haemoconcentration indicated diabetes insipidus, and treatment with vasopressin (" pitressin") was started. The serum potassium concentration was low in contrast with the high serum sodium and chloride levels, and an electrocardiogram showed changes of moderate hypokalaemia. This hypokalaemia was attributed to the large doses of cortisone which the patient had been taking. Over the next 12 hours $3.5 \mathrm{l}$. of fluid and $90 \mathrm{mEq}$ of potassium were given orally with an additional $125 \mathrm{mg}$. cortisone, making a total of $175 \mathrm{mg}$. on this day. The patient improved rapidly and became mentally alert. The dehydration disappeared and the blood pressure became normal with weight gain, a positive fluid balance, and a fall in plasma protein and serum sodium levels. By the third day her clinical state was satisfactory and the extracellular fluid volume, as measured by the bromide space (Nicholson and Zilva, 1957), had expanded by nearly 4 litres to 16.5 litres, correlating closely with the cumulative fluid gain (Fig. 1). At this stage the bromide space was probably a reliable measure of the extracellular fluid volume and was within the normal range for the patient's height and weight.

During this time she had received $1 \mathrm{ml}$. "pitressin" tannate in oil intramuscularly each day (5 pressor units $/ \mathrm{ml}$.), but from the fourth day onwards she deteriorated unexpectedly so that by the eighth day the weight and bromide space had fallen to the same levels as on entry, despite increasing the "pitressin" to $1.5 \mathrm{ml}$. daily on Day 7 . It was then discovered that aqueous "pitressin" ( 20 pressor units $/ \mathrm{ml}$.) had been given in error for the oily suspension of " pitressin" tannate, and, despite a sixfold increase in dosage, had produced no effective overall antidiuretic response. Fig. 1 shows that when this error was corrected the diabetes insipidus was once again controlled. 
Despite this she deteriorated, and by Day 10 was confused, muscles were twitching, and she complained of cramps. The serum sodium level had fallen to $127 \mathrm{mEq} / 1$. and the urinary loss of sodium on this day was $336 \mathrm{mEq}$. Since admission the dose of cortisone had been reduced stepwise and maintained at $75 \mathrm{mg}$. daily from the fourth day onwards. The progressive sodium loss despite hyponatraemia indicated that the sodium-retaining effect of this dose of cortisone was inadequate to maintain a normal sodium balance, and the clinical picture resembled that of acute adrenal insufficiency. During this period (Days 9-15) the bromide space expanded rapidly to 331 ., a value much exceeding the extracellular fluid volume and approximating to the probable total body water. This suggested that bromide had entered the cells, a phenomenon which has been observed in other patients with severe adrenocortical insufficiency or other conditions likely to affect the permeability of cell membranes. At this time the serum bicarbonate, calcium, and urea levels were all normal.

Despite increasing the daily dose of cortisone to $100 \mathrm{mg}$. on Days 10 and 11 , the serum sodium level continued to fall to $113 \mathrm{mEq} /$ litre on Day 13 , when $0.5 \mathrm{mg}$. fluorohydrocortisone daily was started. This potent sodium-retaining hormone caused a striking improvement, and by Day 16 the patient was well again. A further dose of radiobromide was given, and the normal figures for the bromide space on Days 17-19 suggested that adrenocortical substitution therapy was now adequate.

Thereafter she remained well on $75 \mathrm{mg}$. cortisone and 0.25 mg. $9 \alpha$ - fluorohydrocortisone daily by mouth, with $2-4$ units of "pitressin" tannate in oil every other day. She was discharged on Day 20 and returned home, where she led an active life, doing her own housework
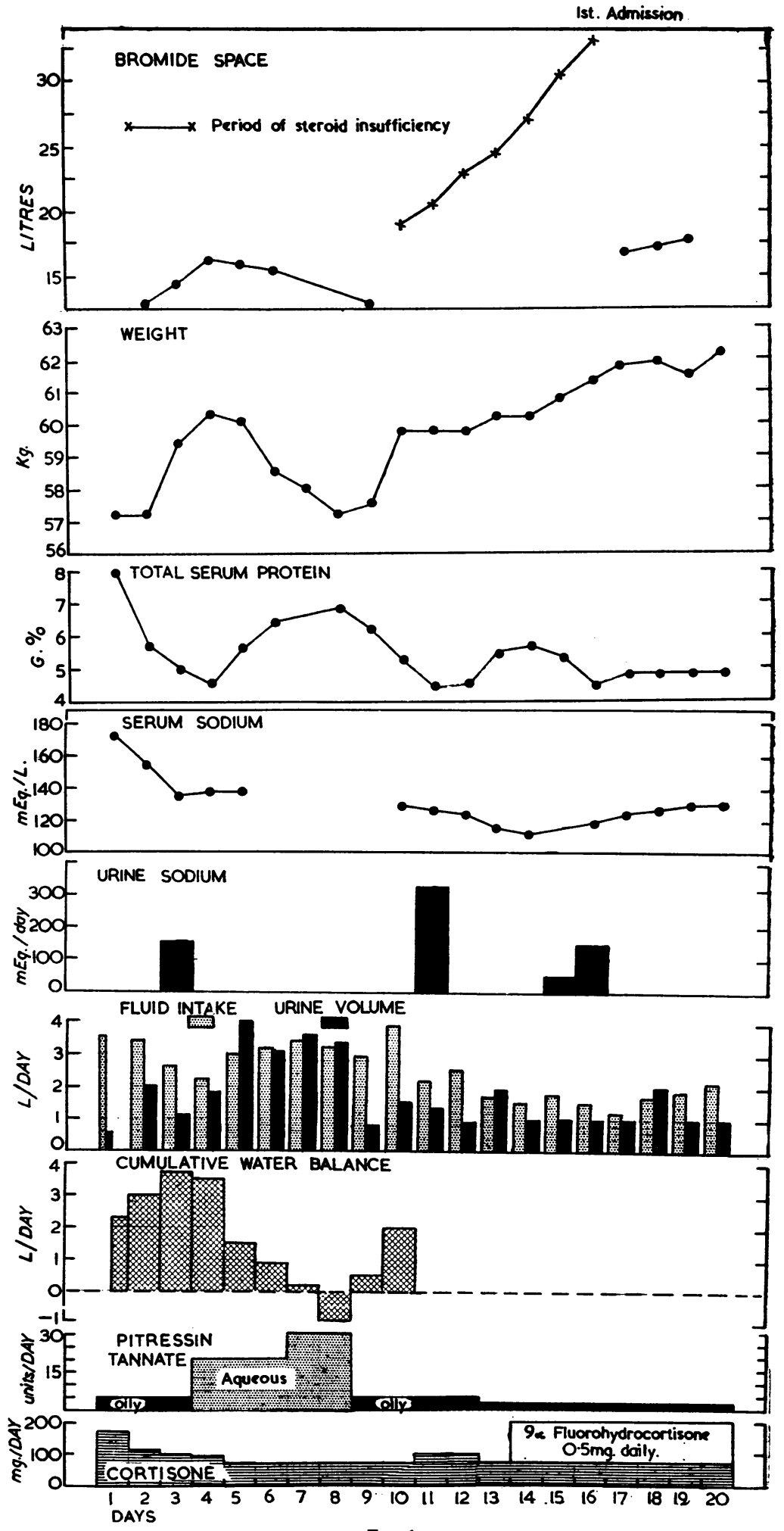

Fio. 1 
and driving a car. The serum sodium level fluctuated between 130 and $156 \mathrm{mEq} / \mathrm{l}$, and a 24-hour assay of urinary steroid excretion showed that the supplements were well absorbed (17-ketosteroids $4.9 \mathrm{mg}$. and 17-hydroxycorticosteroids $25.3 \mathrm{mg}$.).

In October, 1957, attacks of headache and vomiting began, and in February, 1958, an enlarging metastasis in the left femur caused severe pain which led to the patient's readmission. The diabetes insipidus was well controlled and the cerebral symptoms were attributed to metastases. During this admission the effect of varying the dose of "pitressin" tannate was studied while she received a constant steroid supplement of $75 \mathrm{mg}$. cortisone and $0.25 \mathrm{mg}$. fluorohydrocortisone, and a relatively constant sodium intake of $200 \mathrm{mEq}$ daily. Fluid intake was unrestricted and there was no vomiting. At the beginning of this period of observation the patient was not dehydrated and the bromide space of 14.51 . on Day 2 (Fig. 2) was within normal limits. Initially the dose of "pitressin" tannate in oil was 0.5 units

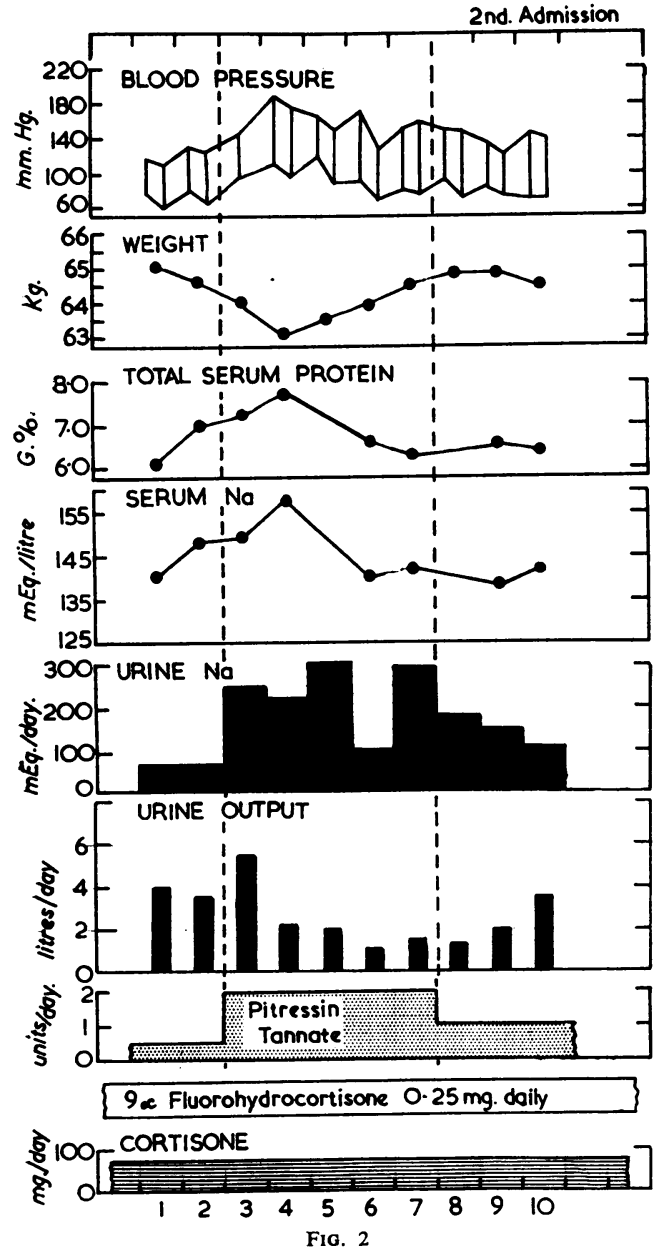

TABLE I

URINARY EXCRETION OF WATER AND ELECTROLYTES IN RELATION TO "PITRESSIN" DOSAGE

\begin{tabular}{|c|c|c|c|c|c|}
\hline & \multirow{2}{*}{$\begin{array}{c}\text { "Pitressin" } \\
\text { Tannate } \\
\text { in Oil } \\
\text { (Units day) }\end{array}$} & \multicolumn{4}{|c|}{ Mean Daily Excretion } \\
\hline & & $\underset{\text { (mEq day) }}{\text { Sodium }}$ & $\begin{array}{l}\text { Potassium } \\
\text { (mEq day) }\end{array}$ & $\begin{array}{l}\text { Chloride } \\
\text { (mEq day) }\end{array}$ & $\underset{\text { (ml. day) }}{\text { Urine }}$ \\
\hline $\begin{array}{l}\text { Period } 1 \\
\text { (2 days) } \\
\text { Period } 2 \\
\text { ( } 5 \text { days) }\end{array}$ & $2^{\frac{1}{2}}$ & $\begin{array}{r}74 \\
234\end{array}$ & $\begin{array}{r}93 \\
100\end{array}$ & $\begin{array}{l}162 \\
236\end{array}$ & $\begin{array}{l}3,730 \\
2,375\end{array}$ \\
\hline $\begin{array}{r}\text { Period } 3 \\
\text { ( } 3 \text { days) }\end{array}$ & 1 & 151 & 100 & 188 & 2,340 \\
\hline
\end{tabular}

daily, and the average urine volume on Days 1 and 2 was $3,730 \mathrm{ml}$. (Table I), indicating that the diabetes was not completely controlled. On Day 3 the dose of " pitressin" tannate was increased to 2 units daily. The effect of this was delayed but was followed by an increase in blood pressure and in urinary sodium excretion. On the first day of this dosage the urine volume increased to $5 \mathrm{l}$. and was associated with haemoconcentration, as shown by the rise in serum sodium and plasma protein concentrations on Days 3 and 4 . On the fourth day the urine volume fell and thereafter better control of the diabetes insipidus was obtained, judging from the urine volume, gain in weight, and return of the serum sodium and plasma protein levels to normal. Reducing the dose of "pitressin" tannate to 1 unit daily on Day 8 was accompanied by a gradual fall in sodium excretion and a gradual increase in urinary volume, suggesting that this dose did not quite control the diabetes insipidus. The pattern of these responses showed that there was some delay in the absorption of "pitressin" tannate in oil from the site of injection. Thus the maximum effect of 2 units daily was not evident for 24 to 48 hours and the increased diuresis caused by halving the dose of "pitressin" on Day 8 was delayed for a similar period.

On Day 2 the total exchangeable sodium, measured with radiosodium, was $3,450 \mathrm{mEq}(54 \mathrm{mEq} / \mathrm{kg}$. body weight), an abnormally high figure. The total exchangeable potassium at the end of the study was abnormally low at $1,280 \mathrm{mEq}(21 \mathrm{mEq} / \mathrm{kg}$. body weight). These findings suggested that the amount of adrenocortical substitution therapy was excessive, and the dose of fluorohydrocortisone was reduced after Day 10 to $0.1 \mathrm{mg}$. daily. Later the dose of cortisone was increased to $150 \mathrm{mg}$. daily, but this did not influence the response to a constant amount of " pitressin" tannate.

\section{Discussion}

The modern treatment of advanced carcinoma of the breast may so prolong life that the rarer complications of metastases, such as diabetes insipidus, may occur more frequently. Retrospective study of this patient's fluid chart after adrenalectomy shows urine volumes of 3 to 6 litres daily and a negative fluid halance, indicating the 
onset of diabetes insipidus although she did not then complain of thirst.

As a result of adrenalectomy and destruction of the neurohypophysis, the hormonal control of both salt and water balance was lost. Thus initially, whilst receiving large doses of cortisone but deficient in antidiuretic hormone, sodium was retained despite the polyuria, and the clinical picture was that of water depletion. At this stage the patient resembled the case described by Engstrom and Liebman (1953) in whom diabetes insipidus complicated anterior pituitary failure. However, by Day 3 (Fig. 1) the fluid deficit had been corrected with " pitressin" tannate in oil, but thereafter (Days 4-7) progressive sodium and water depletion occurred as a result of the reduced dose of cortisone and the unsuitable preparation of vasopressin. The loss of water was shown by the fall in weight, the low bromide space, and the haemoconcentration on Day 9. When " pitressin" tannate was re-started water balance was restored, but by Day 10 severe salt depletion was revealed with a serum sodium of $127 \mathrm{mEq} /$ litre and a urinary sodium loss of $336 \mathrm{mEq}$ on this day, indicating insufficient sodium-retaining hormone. Only when sodium retention was increased with fluorohydrocortisone was correct salt and water balance achieved. The wide fluctuation in serum sodium levels when the patient was an out-patient shows that this balance was precarious, but her satisfactory clinical state suggests that a reasonable compromise was obtained.

\section{Influence of Cortisone on Polyuria in Diabetes Insipidus}

Several reports have shown that the thirst and polyuria of experimental diabetes insipidus are reduced if the anterior pituitary is destroyed or the adrenal glands removed (Biggart and Alexander, 1939; Ingram and Winter, 1938 ; Gaunt, Birnie, and Eversole, 1949). This fall in urine volume, despite continuing lack of antidiuretic hormone (ADH), is probably due to several factors, particularly a decrease in the solute-load requiring excretion and the reduction in glomerular filtration rate. Leaf and his associates (1952) showed in a patient with loss of both anterior and posterior pituitary function that lack of ADH, as shown by an inability to elaborate a concentrated urine, persisted, and the absence of polyuria depended upon the reduction in solute load. When this was increased the polyuria recurred, and when the solute load was kept constant cortisone had no effect on water excretion. These findings suggest that the influence of cortisone on the polyuria was due to its general metabolic effect which led to an increase in solute excretion.

Cortisone also increases urine flow in patients with adrenocortical insufficiency by increasing the glomerular filtration rate. Burston and Garrod (1952) found in Addisonian patients that the rate of urine flow up to $5 \mathrm{ml}$./min. depended upon the glomerular filtration rate, and Skillern et al. (1956) also concluded in their patient with Addison's disease and diabetes insipidus that the diuresis induced by hydrocortisone was attributable to an increase in the glomerular filtration rate.

It has also been suggested that cortisone may antagonize the action of antidiuretic hormone on the renal tubules (Gaunt et al., 1949), but in our patient doubling the dose of cortisone from 75 to $150 \mathrm{mg}$. daily did not influence the requirement of " pitressin" tannate.

\section{Influence of Antidiuretic Hormone on Electrolyte Excretion}

There are many conflicting reports on the effect of "pitressin" on sodium and chloride excretion depending partly on species variation and partly on the degree of preliminary hydration. In normal subjects " pitressin " does not affect sodium output (Black and Thomson, 1951) though at low rates of urine flow a slight fall in sodium excretion may occur (Murphy and Stead, 1951). Under artificial conditions, when the extracellular fluid volume is expanded by pitressin a delayed sodium diuresis results (Leaf, Bartter, Santos, and Wrong, 1953). This is accompanied by potassium retention and is attributed to secondary inhibition of aldosterone production (Liddle, Bartter, Duncan, Barber, and Delea, 1955 ; Wrong, 1956).

In the case of anterior and posterior pituitary failure reported by Engstrom and Liebman (1953) "pitressin", had no effect on sodium excretion, and, though Leaf et al. (1952) comment on the natriuresis produced by "pitressin" in their patient, this effect took three days to become fully apparent. It was probably not a direct effect of "pitressin" but due to secondary inhibition of sodium-retaining mechanisms.

The variation in urinary sodium and chloride excretion with "pitressin" dosage in the patient being discussed, on fixed doses of adrenocortical steroid, is therefore surprising. There is some day-to-day variation within the periods and the findings must be viewed with some suspicion. The diet, however, was constant and potassium excretion was fairly uniform throughout. She was 
adequately hydrated at the beginning of the investigation and the dose of cortisone and $9 \alpha$ fluorohydrocortisone seemed adequate. Some support to the findings is given by the fact that after adrenalectomy she was adequately maintained on $50 \mathrm{mg}$. cortisone orally, whereas, when receiving "pitressin," double this dose did not prevent sodium depletion (Days 10-11, see Fig. 1).

The increase in sodium excretion was not delayed, was not accompanied by potassium retention, and therefore cannot be explained by changes in sodium-retaining hormones. In the presence of severe renal disease sodium excretion may vary with the blood pressure as a result of changes in renal plasma flow. In this patient renal function was normal (blood urea $27 \mathrm{mg}$. \% on Day 2), and this mechanism seems unlikely. Furthermore, Murphy and Stead (1951) have shown that " pitressin" in physiological doses does not affect renal plasma flow or glomerular filtration. It may be that the increased sodium excretion is a direct effect of " pitressin," normally masked by simultaneous changes in sodiumretaining mechanisms, an explanation which is physiologically acceptable but without supporting experimental evidence.

This combination of endocrine defects proved difficult to treat, especially as sodium depletion may be masked by the diabetes insipidus. If a satisfactory preparation of "pitressin" is used, water balance is readily restored and steroid dosage must then be adjusted according to the serum electrolytes and urinary sodium excretion.

\section{Summary}

A patient* is reported in whom diabetes insipidus developed following total adrenalectomy for carcinomatosis.

During treatment syndromes of sodium and water depletion were seen which varied independently.

Aqueous "pitressin" was of no value in treatment even in high dosage, whereas oily "pitressin" tannate was very satisfactory.

An unusually high dosage of steroid was required for maintenance.

Sodium excretion appeared to vary with " pitressin" dosage.

We wish to thank Sir Stanford Cade for permission to publish this case. We are indebted to Dr. R. I. S. Bayliss and Professor N. F. Maclagan for their advice in the preparation of this paper. The illustrations were prepared by Miss Jeanette Pirkis.

\section{REFERENCES}

Biggart, J. H., and Alexander, G. L. (1939). J. Path. Bact., 48, 405. Black, D. A. K., and Thomson, A. E. (1951). Clin. Sci., 10, 511 Burston, R. A., and Garrod, O. (1952). Ibid., 11, 129

Engstrom, W. W., and Liebman, A. (1953). Amer. J. Med., 15, 181. Gaunt, R., Birnie, J. H., and Eversole, W. J. (1949). Physiol. Rev. 29, 281

Ingram, W. R., and Winter, C. A. (1938). Amer. J. Physiol., 122, 143. Leaf, A., Bartter, F. C., Santos, R. F., and Wrong, O. (1953). J. clin. Invest., 32, 868.

Mamby, A. R., Rasmussen, H., and Marasco, J. P. (1952) Ibid., 31, 914.

Liddle, G. W., Bartter, F. C., Duncan, L. E., Barber, J. K., and Delea, C. (1955). Ibid., 34, 949

Lipsett, M. B., and Pearson, O. H. (1957). J. Lab. clin. Med., 49, 190. Murphy, R. J. F., and Stead, E. A. (1951). J. clin. Invest., 30, 1055.

Nicholson, J. P., and Zilva, J. F. (1957). Clin. Chim. Acta, 2, 340.

Skillern, P. G., Corcoran, A. C., and Scherbel, A. L. (1956). J. clin. Endocr., 16, 171.

Wrong, O. (1956). Clin. Sci., 15, 401.

* Since this paper was written, the patient has died. Unfortunately no necropsy could be performed. 